\title{
Planting Times and Varieties on Incidence of Bacterial Disease and Yield Quality of Broccoli during Rainy Season in Southern Thailand
}

\author{
Karistsapol Nooprom ${ }^{1} \&$ Quanchit Santipracha ${ }^{1}$ \\ ${ }^{1}$ Department of Plant Science, Faculty of Natural Resources, Prince of Songkla University, Hat Yai, Songkhla \\ 90112, Thailand \\ Correspondence: Karistsapol Nooprom, Department of Plant Science, Faculty of Natural Resources, Prince of \\ Songkla University, Hat Yai, Songkhla 90112, Thailand. E-mail: abhichard_n@hotmail.co.th
}

Received: August 9, $2013 \quad$ Accepted: October 29, $2013 \quad$ Online Published: November 11, 2013

doi:10.5539/mas.v7n12p9 URL: http://dx.doi.org/10.5539/mas.v7n12p9

\begin{abstract}
The aims of this study were to determine the effect of planting times and varieties on incidence of bacterial disease and yield quality of broccoli grown during rainy season in southern Thailand. The research was carried out at Prince of Songkla University from July, 2011 to January, 2012. The design was a split-plot in a randomized complete block with four replications. The result showed that the Yok Kheo grown in July was observed with the lowest incidence of soft rot disease of $27.68 \%$ while the highest incidence of $80.11 \%$ was found in the Top Green when planting in November. In July, all varieties of broccoli had not been affected by black rot disease. After that, their incidences increased when planting between August and December. The four broccoli varieties had the highest disease incidence of $87.42-97.57 \%$ when planting in October, followed by September, November and December of 74.72-94.97\%. The Yok Kheo had the highest yield quality when planting in July and December with total yield of 4.70-5.29 t/ha. It is an interesting new hybrid variety. It gave higher yield quality than Top Green which is popular variety grown in southern Thailand.
\end{abstract}

Keywords: Brassicaceae, bacterial disease, Thailand, tropical region, planting time, yield quality

\section{Introduction}

Broccoli (Brassica oleracea var. italica) is one of the winter vegetable cole crops, which has more nutrition than other coles, such as cabbage (Brassica oleracea var. capitata), cauliflower (Brassica oleracea var. botrytis), and kohlrabi (Brassica oleracea var. gongylodes). It is environmentally better adapted and can tolerate comparatively high temperature than cauliflower (Mahmud et al., 2007). However, the broccoli yield in southern Thailand is very low compared to other areas of Thailand, highland where the weather is cool or in lowlands during cool season (Nooprom et al., 2013). One of the reasons responsible for lower yield is bacterial disease which may be due to unsuitable environments.

Soft rot disease (head rot) of broccoli commonly plagues commercial planting when head maturation coincides with periods of prolonged rainy, wet weather. The disease is caused by Erwinia carotovora ssp. carotovora (Canaday \& Wyatt, 1992). It can be found on crop in the field, in transit and in storage or during marketing resulting in great economical losses. Soft rot disease causes greater total loss of production than other bacterial diseases. This bacterium enters plant tissue primarily through wound, often created by insect feeding. Insect and water are effective modes in spreading the bacteria (Bhat et al., 2010). Disease affects both forest and stem tissue. It appears first as a water-soaked lesion followed by maceration and soft rotting of tissue (Ludy \& Powelson, 1997).

Black rot disease is one of the serious diseases at seedling and planting stages resulting from infected seeds (Dutta et al., 2011). Black rot disease of Brassicaceae, caused by Xanthomonas campestris pv. campestris, is known in most major agricultural countries in the world, including Thailand. Several cruciferous crops, including cabbage, cauliflower and broccoli, are important in Thailand (Schaad \& Thaveechai, 1983). Bacterium colonizes in the vascular system and the characteristic black rot system in V-shaped lesion at leaf margins with black veins, chlorosis and necrosis (Kocks \& Zadoks, 1996). The disease can cause significantly yield losses when warm, humid conditions follow period of rainy weather early crop development (Dutta et al., 2011). 
The weather of southern Thailand is quite humid tropics. It has suitability for growing heat-tolerant varieties of broccoli which are better adapted to the high temperature in humid tropical regions (Nooprom \& Santipracha, 2011). However, due to suitable environment for pathogens, the spreading of soft rot and black rot diseases can be found in broccoli production, and causes the growth and yield losses.

The objectives of this study were to determine the relationship between planting times and varieties on incidence of bacterial disease and yield quality of broccoli during rainy season in southern Thailand.

\section{Materials and Methods}

This study was conducted at Prince of Songkla University, Hat Yai, Songkhla province, Thailand from July, 2011 to January, 2012. The design was a split-plot in a randomized complete block. The main plots were planting dates: January, February, March, April, May, and June with sub-plots being early varieties of broccoli: Top Green, Green Queen, Yok Kheo, and Special. Broccoli seed was sown in plastic baskets $(13 \times 16 \times 4$ inches $)$. When the first true leaf had emerged, the seedlings were transplanted into 2 inch pots. At the fourth leaf stage, the seedlings were transplanted into the field. The plot size was $1 \times 5 \mathrm{~m}$. The plant and row spacing were $0.30 \times 0.60 \mathrm{~m}$ and the edge spacing was $0.2 \mathrm{~m}$. Each plot had two rows of 32 plants. The broccoli was regularly watered with a sprinkler early in the morning and early in the afternoon except rainy days. Fertilizer $21 \mathrm{~N}-0 \mathrm{P}-0 \mathrm{~K}$ was applied three times at 2, 3 and 4 weeks after transplanting. Moreover, fertilizer 15N-6.5P-12.5K was applied twice at 5 and 6 weeks after transplanting. All plots were weeded with a hand hoe twice at 2 and 4 weeks after transplanting.

The incidence rates (\%) of soft rot and black rot diseases were calculated from infected plants in each plot. The yield quality data was measured from head diameter $(\mathrm{cm})$, head weight $(\mathrm{g} / \mathrm{plant})$, and total yield $(\mathrm{t} / \mathrm{ha})$. Data of average daily rainfall, minimum and maximum temperatures from July, 2011 to January, 2012 was obtained from the Kho Hong Agrometeorological Station, Hat Yai, Songkhla, Thailand. Comparison among means was done with the analysis of variance and means separated by Duncan's multiple range test (DMRT) at the 5\% level of significance.

\section{Results and Discussion}

\subsection{Incidence of Soft Rot Disease}

The highest incidence of soft rot disease of $67.42 \%$ was observed when planting was done in September which was not significantly different from incidence of $65.68 \%$ when planting in November, followed by planting in August, October, and December of 50.13-59.00\%. In January, soft rot incidence was the lowest of 44.16\%. The highest incidence was observed in the Top Green, Green Queen, and Special of 58.56-63.25\% while the Yok Kheo had the lowest incidence of soft rot disease of $46.53 \%$. The interactions between planting times and varieties were significantly influenced on the soft rot incidence. The Yok Kheo grown in July was observed with the lowest incidence of $27.68 \%$ as shown in Figure 2. The highest disease incidence was found in the Top Green when planting in November of $80.11 \%$. High incidence of soft rot disease observed in September and November might be due to high temperature of $25.40-35.10{ }^{\circ} \mathrm{C}$ in that period, as well as continuously heavy raining (Figure 1) that caused increasing relative humidity. Vudhivanich (2006) reported that high temperature about $30-36{ }^{\circ} \mathrm{C}$ and high relative humidity cause increasing incidence of soft rot disease in Brassicaceae family. This report was consistent with Kucharek and Bartz (2000) that high temperature and relative humidity had suitability on soft rot disease cultivation and spreading. 


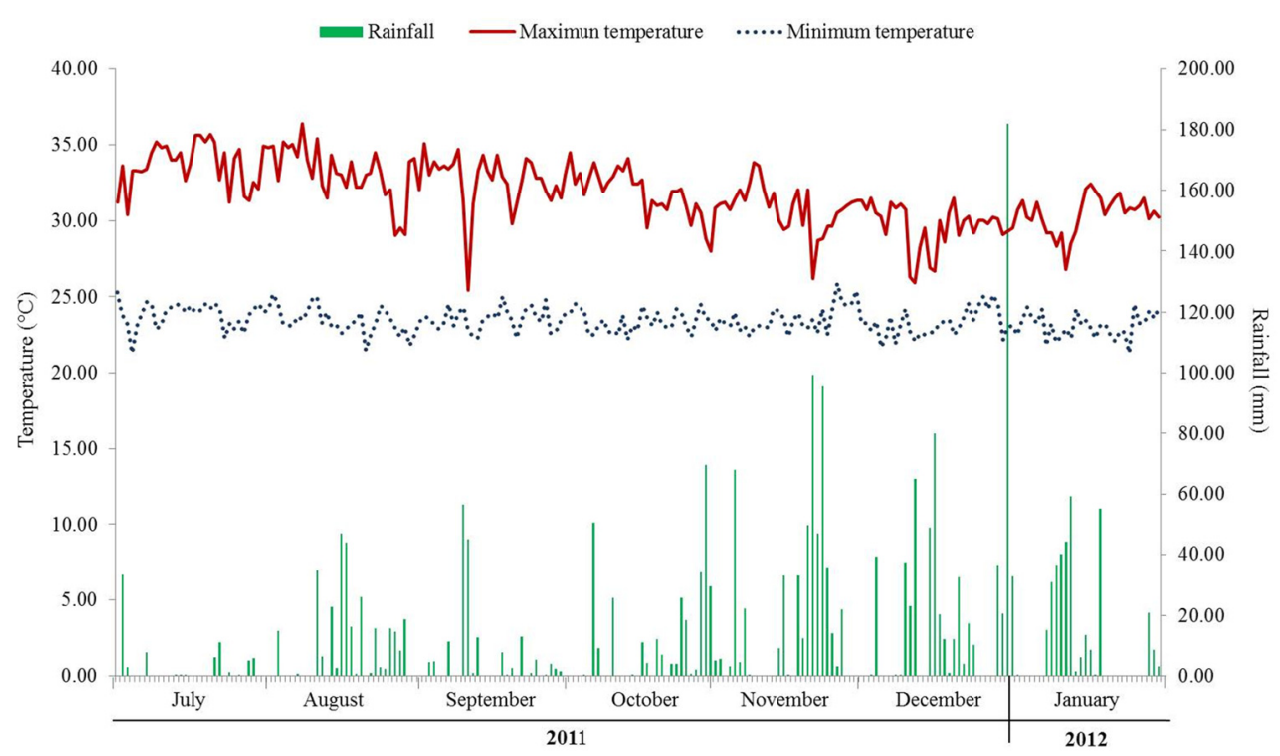

Figure 1. Daily rainfall, maximum and minimum temperatures from July, 2011 to January, 2012

(Source: Kho Hong Agrometeorological Station, Hat Yai, Songkhla province, Thailand)

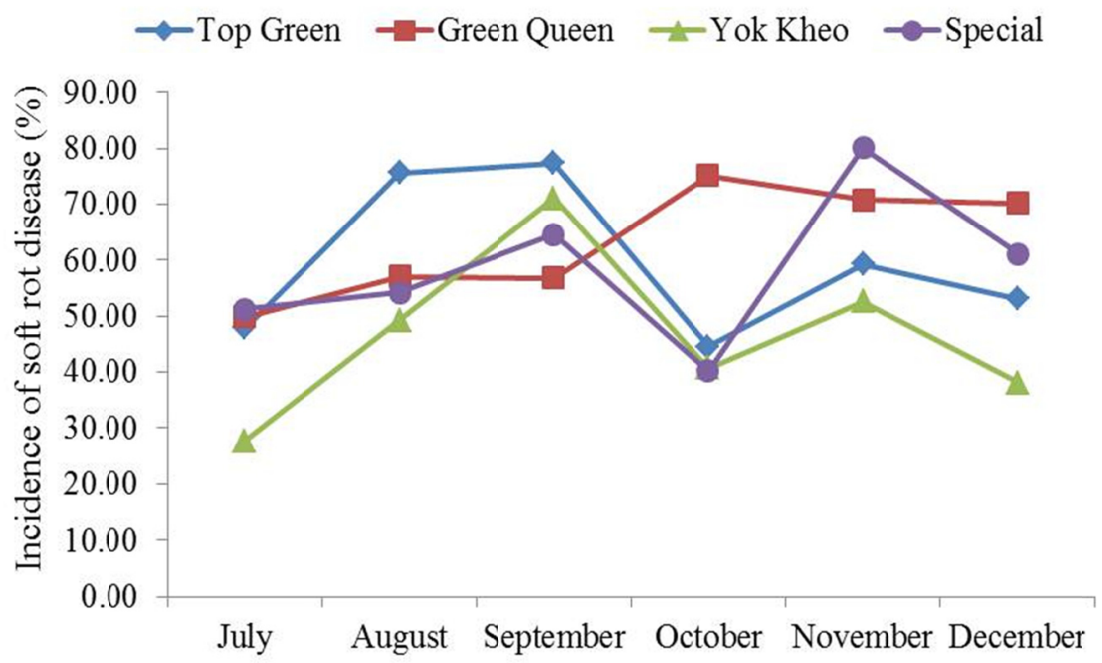

Figure 2. Interactions between planting times and broccoli varieties on incidence of soft rot disease

\subsection{Incidence of Black Rot Disease}

Broccoli planting in October was observed the highest black rot incidence of $94.10 \%$. Disease incidence was decreased when planting in November, December, September, and August of 86.44\%, 80.31\%, 78.65\%, and $59.29 \%$, respectively. No black rot disease was found in July. The four varieties of broccoli had high incidences of black rot disease of 78.48-81.52\% when planting in all months. The interactions of planting times and varieties of broccoli revealed that all varieties grown in July had not been affected by black rot disease. After that, their incidences increased when planting between August and December (Figure 3). The four broccoli varieties had the highest disease incidences of $87.42-97.57 \%$ when planting in October, followed September, November, and December of 74.72-94.97\%. High incidence was observed from September to December because of high temperature of $25.40-35.10^{\circ} \mathrm{C}$ and continuous raining (Figure 1). These settings were suitable for the growth and spreading of black rot disease. Schaad and Thaveechai (1983) reported that humid tropical climate had suitability on black rot disease spreading. This report consistent with Vudhivanich (2006) that black rot disease well spreading when it obtained high temperature about $25-35^{\circ} \mathrm{C}$. 


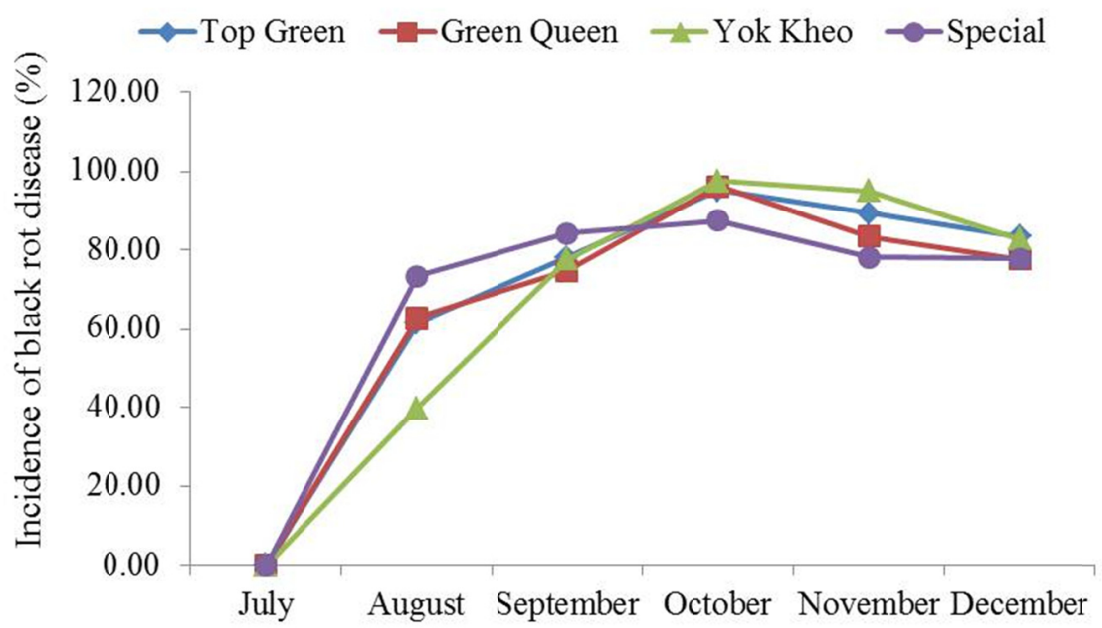

Figure 3. Interactions between planting times and broccoli varieties on incidence of black rot disease

\subsection{Head Diameter}

Effect of planting times and varieties on yield quality revealed that broccoli grown in July was obtained the highest head diameter of $10.62 \mathrm{~cm}$, followed by of 9.28-9.70 cm in August and December. Broccoli planting in September and November had the lowest head diameter of 8.32-8.60 cm. The Yok Kheo had the highest head diameter of $10.74 \mathrm{~cm}$, followed by the Top Green of $10.04 \mathrm{~cm}$. The Green Queen and Special had the lowest head diameter of 8.60-9.02 cm, respectively. The interactions of planting times and varieties of broccoli revealed that the Yok Kheo planting in January got the highest head diameter of $13.18 \mathrm{~cm}$, and the lowest head diameter of 8.25-8.92 cm was obtained in the Special when planting in all months (Figure 4).

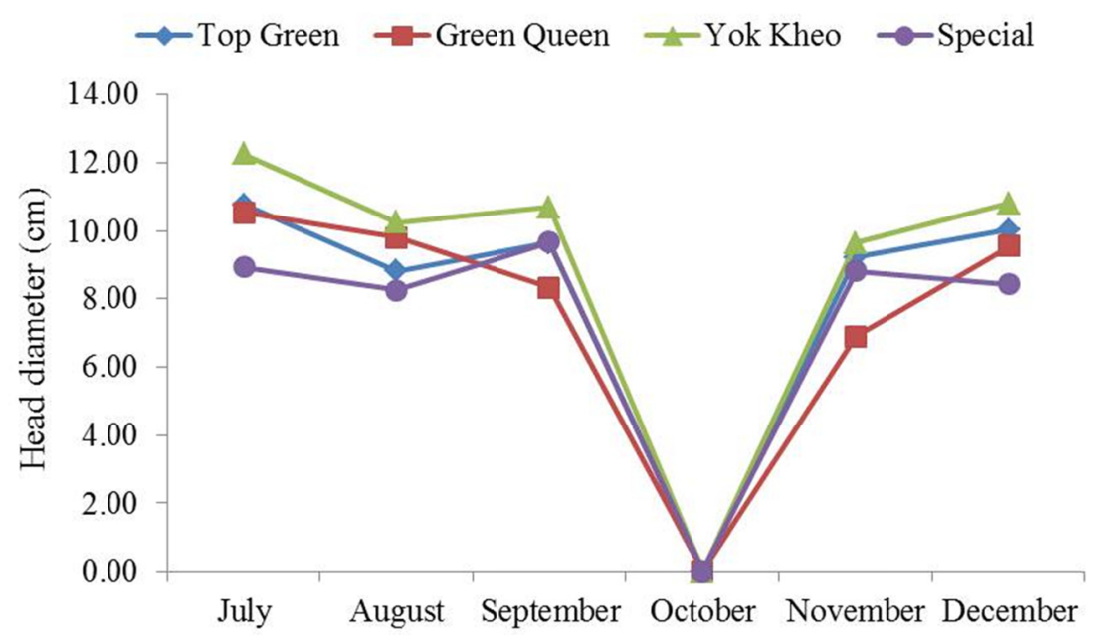

Figure 4. Interactions between planting times and broccoli varieties on head diameter

\subsection{Head weight}

Broccoli planting in July, August, and December had the highest head weight of 228.36-244.69 g/plant. In September and November, broccoli plants had decreasing head weight of 147.92 and $166.06 \mathrm{~g} / \mathrm{plant}$, respectively. The Yok Kheo had the highest head weight of $256.41 \mathrm{~g} / \mathrm{plant}$, followed by the Top Green, Green Queen, and Special of 208.69, 203.14, and $191.89 \mathrm{~g} / \mathrm{plant}$, respectively. The interactions between planting times and varieties showed that the Yok Kheo was obtained the highest head weight of 266.47-304.77 g/plant when planting in July, August, and December, followed by the Green Queen of 254.41-260.19 g/plant when planting in July and August (Figure 5). 


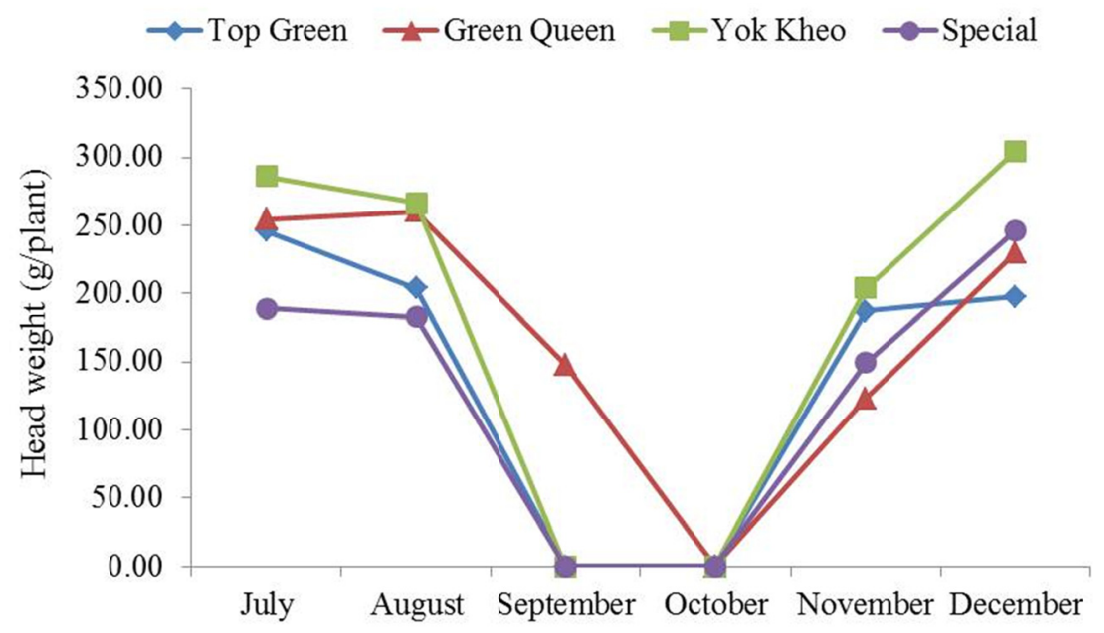

Figure 5. Interactions between planting times and broccoli varieties on head weight

\subsection{Total Yield}

Broccoli planting in July and December were obtained the highest total yield of 4.73-5.29 t/ha while planting in August, September, and November had the lowest total yield of 1.68-2.90 t/ha. The Yok Kheo produces the highest total yield of $5.67 \mathrm{t} / \mathrm{ha}$ whileas the Top Green, Green Queen, and Special had low total yield of 2.44-3.33 $\mathrm{t} / \mathrm{ha}$. The interaction effect for total yield was different in each variety over the range of planting times. Planting in July and December, the Yok Kheo had the highest total yield of 7.73-7.87 t/ha, followed by the Top green of 4.70-5.04 t/ha (Figure 6).

The four broccoli varieties had the lowest yield quality when planting in September and October because there was continually heavy raining and maximum temperature of $31.89-32.60{ }^{\circ} \mathrm{C}$ in this period as shown in Figure 1. These environments are suitable for spreading of bacterium Erwinia corotovora ssp. corotovora and Xanthomonas campestris pv. campestris that cause soft rot and black rot diseases. Krauthausen et al. (2011) and Vudhivanich (2006) reported that black rot and soft rot diseases caused growth and yield of Brassicaceae family.

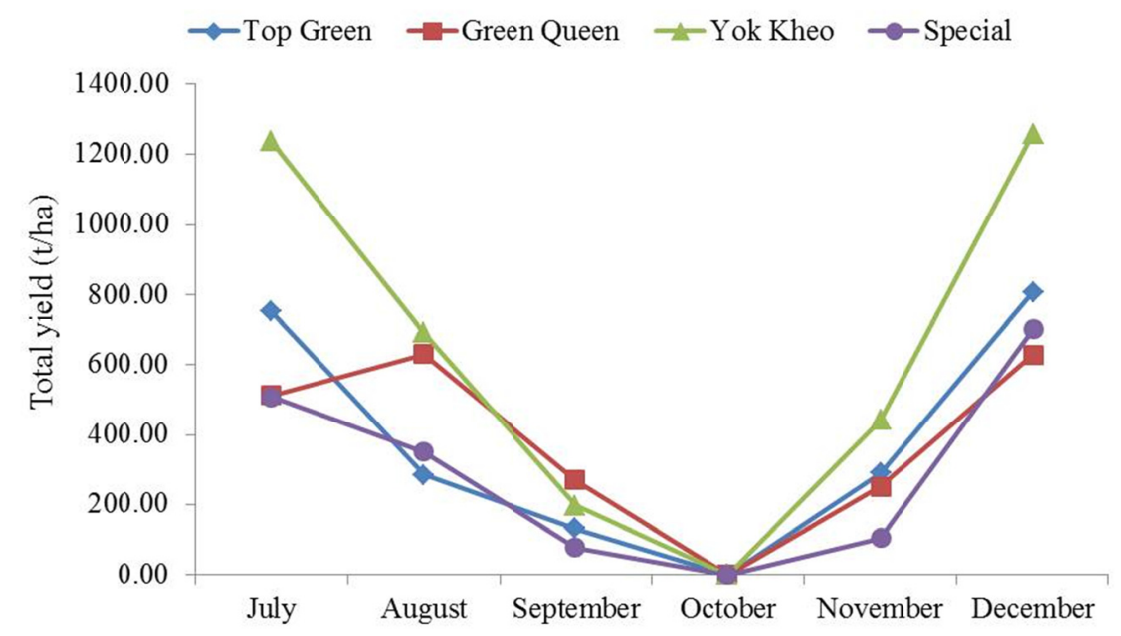

Figure 6. Interactions between planting times and broccoli varieties on total yield

\section{Conclusion}

This study showed that rainy season in southern Thailand is unsuitable for broccoli production because there was high incidence of soft rot and black rot diseases in this period ( $>50 \%)$. Except in July and December, in spite of high incidence of disease, higher yield quality can be obtained than other months. The Yok kheo is the suitable variety for commercial production during rainy season in southern Thailand because it can be resist well to bacterial diseases and give high yield quality. 


\section{Acknowledgments}

This work was funded by a grant from The Office of the Higher Education Commission of Thailand. Mr. Karistsapol Nooprom was supported by CHE Ph.D. Scholarship. The authors would like to thank The Graduate School and Department of Plant Science, Faculty of Natural Resources, Prince of Songkla University, Hat Yai, Songkhla, Thailand for supporting the scholarship, experimental equipment and the field that the broccoli was planted in.

\section{References}

Bhat, K. A., Masoodi, S. D., Bhat, N. A., Ahamad, M., Zargar, M. Y., Mir, S. A., \& Bhat, M. A. (2010). Studies on the effect of temperature on the development of soft rot of cabbage (Brassica oleracea var. capitata) caused by Erwinia carotovora sub sp. carotovora. Journal of Phytology, 2(2).

Canaday, C. H., \& Wyatt, J. E. (1992). Effects of nitrogen fertilization on bacterial soft rot in two broccoli cultivars, one resistant and one susceptible to the disease. Plant Disease, 76, 989-991. http://dx.doi.org/10.1094/PD-76-0989

Dutta, S., Thapa, G., Barman, A. R., Hembram, S., \& Khatua, D. C. (2011). Prediction of black rot disease progression of cabbage based on weather parameters. Rajshahi University Journal of Environmental Science, 1, 30-33.

Kocks, C. G., \& Zadoks, J. C. (1996). Cabbage refuse piles as sources of inoculums for black rot epidemics. Plant Disease, 80, 789-792. http://dx.doi.org/10.1094/PD-80-0789

Krauthausen, H. J., Laun, N., \& Wohanka, W. (2011). Methods to reduce the spread of the black rot pathogen, Xanthomonas campestris pv. campestris, in brassica transplants. Journal of Plant Disease and Protection, $118(1), 7-16$.

Kucharek, T., \& Bartz, J. (2000). Bacterial soft rot of vegetables and agronomic crops. Retrieved from http://university.uog.edu/cals/people/PUBS/DiseaseP/VH01200.pdf

Ludy, R. L., \& Powelson, M. L. (1997). Effect of sprinkler irrigation on bacterial soft rot and yield of broccoli. Plant Disease, 81(6), 614-618. http://dx.doi.org/10.1094/PDIS.1997.81.6.614

Mahmud, S., Haider, M., Moniruzzaman, M., \& Islam, M. R. (2007). Optimization of fertilizer requirement for broccoli under field condition. Bangladesh journal of agricultural research, 32(3).

Nooprom, A., \& Santipracha, Q. (2011). Growth and yield of 7 early varieties of broccoli in Songkhla province. King Mongkut's Agricultural Journal, 19(2), 54-61.

Nooprom, K., Santipracha, Q., \& Sompong, T. (2013). Effect of shading and variety on the growth and yield of broccoli during the dry season in southern Thailand. International Journal of Plant, Animal and Environmental Sciences, 3(2). Retrieved from http://www.ijpaes.com/admin/php/uploads/321_pdf.pdf

Schaad, N. W., \& Thaveechai, N. (1983). Black rot of crucifers in Thailand. Plant Disease, 67, 1231-1234. http://dx.doi.org/10.1094/PD-67-1231

Vodhivanich, S. (2006). Vegetable Diseases and Their Control. Bangkok, BKK: Kasetsart University Press.

\section{Copyrights}

Copyright for this article is retained by the author(s), with first publication rights granted to the journal.

This is an open-access article distributed under the terms and conditions of the Creative Commons Attribution license (http://creativecommons.org/licenses/by/3.0/). 